\title{
Consumers' Determination of Red Meat and Meat Products Purchase Behaviour - City of Ankara Sample
}

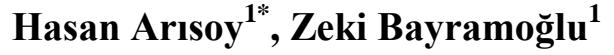 \\ ${ }^{I}$ Department of Agricultural Economics, Faculty of Agriculture, Selcuk University, 42075 Konya, Turkey
}

\section{ART I C LE INF O}

Article history:

Received 12 May 2014

Accepted 24 June 2014

Available online, ISSN: 2148-127X

Keywords:

Red meat

Purchase behavior

Food reliability

Consumer

Sampling method

${ }^{*}$ Corresponding Author:

E-mail: arisoy@selcuk.edu.tr

\section{A B S T R A C T}

Nowadays, meat consuming level is an indicator of development of countries. The reason for this is the importance of animal proteins such as meat, milk and egg in human nutrition. People in Turkey do not get enough animal protein. Increase of meat and meat related product prices is effective on this. The purpose of this study is to bring up the purchase and consume behavior of consumers. Surveys completed in urban areas around city of Ankara are used primarily. Using Main Mass Ratio Based Simple Occurrence Probability Sampling method 338 families were interviewed. Completed surveys were separated into 3 groups; high, middle, low. As a result of the research, expense for food in total income is around $\% 34$. This ratio for families with low income is $\% 53$, for families with middle income is $\% 35$ and for families with high income is $\% 33$. It is found that as income levels of consumers raised, food expenses raise as well. But it shows that as income level increases, expense ratio for food decreases. Food reliability is the most effective factor on consumers' decision of purchase. Studies show doubts of consumers about food reliability. It is understood that legal adjustments are not applied enough. Especially tight food inspections would be positive on consumer behavior.

Türk Tarım - Gıda Bilim ve Teknoloji Dergisi, 3(1): 28-34, 2015

\section{Kırmızı Et ve Et Ürünleri Tüketicilerinin Satın Alma Davranışlarının Belirlenmesi - Ankara İli Örneği}

\section{A K A L E B İ L G İ S İ}

Geliş 12 Mayıs 2014

Kabul 24 Haziran 2014

Çevrimiçi baskı, ISSN: 2148-127X

\section{Anahtar Kelimeler:}

Kırmızi et

Satın alma davranışı

Gıda güvenilirliği

Tüketici

Örnekleme yöntemi

"Sorumlu Yazar:

E-mail: arisoy@ selcuk.edu.tr

\section{Ö Z E T}

Günümüzde hayvansal ürün tüketim düzeyi, ülkelerin gelişmişlik göstergesi olarak da ele alınmaktadır. Bunun nedeni; et, süt, yumurta gibi hayvansal proteinli gıdaların insan beslenmesindeki önemidir. Türkiye'de insanlar yeteri kadar hayvansal protein almamaktadır. Bunda son yıllarda, kırmızı et ve et ürünleri fiyatlarının artmasının etkisi vardır. Bu çalışma ile tüketicilerin et ve et ürünleri tüketim alışkanlığı ve satın alma davranışlarının ortaya konması amaçlanmıştır. Ankara ili kentsel kesimde yaşayan hane halkları ile yapılan anketlerden elde edilen birincil veriler kullanılmıştır. Ana Kitle Oranlarına Dayalı Basit Tesadüfî Olasılık Örneklemesi yöntemi kullanılarak 338 hane halkı ile görüşülmüştür. Yapılan anketler düşük, orta, yüksek olmak üzere üç ayrı gelir grubu halinde değerlendirilmiştir. Araştırma sonucuna göre hanelerin toplam geliri içerisinde gıda harcamalarının payı yaklaşık \%34'dür. Bu oran düşük gelir grubunda yer alan hanelerde $\% 53$, orta gelir düzeyinde $\% 35$ ve yüksek gelir düzeyinde $\% 33$ bulunmuştur. Tüketicilerin gelir düzeyleri arttıkça gıda harcamalarının da arttığı belirlenmiştir. Ancak gelir düzeyi attıkça, gıda harcamalarının toplam gelir ve toplam harcamalar içindeki payının azaldığı görülmektedir. Tüketicilerin satın alma kararında etkili olan faktörlerin başında gıda güvenilirliği gelmektedir. Elde edilen bulgular tüketicilerin gıda güvenirliği konusundaki şüphelerini açıkça ortaya koymaktadır. Yapılan yasal düzenlemelerin uygulamaya yeterince aktarılamadığı anlaşılmaktadır. Özellikle gıda denetimlerinin daha sıkı yapılması, tüketicilerin tüketim alışkanlığı üzerinde olumlu etki yapacaktır. 


\section{Introduction}

There are a lot of factors affecting the development of a country. One of the most important factors is growing healthy and educated individuals (Unver and Unusun, 2005). In order to grow healthy individuals they should be nourished with a sufficient and well-balanced diet (Karabacak and Direk, 2007). As a matter of fact, sufficient and well-balanced nourishment is considered as an indicator of development along with education and healthcare (Yagmur and Gunes, 2010).

Well-balanced nourishment, which is important for human health and efficiency, is possible with certain levels of variety, quality and amount of nutrients. 75-80 gr of protein daily for an adult is enough for wellbalanced nourishment. But almost half (30-35 gr/daily) of this protein should be animal based. Animal protein consists of meat and meat products from mostly cattle (Ilgu and Gunes, 2002).

Meat and meat products are described as follows, "bovines and ovines as cattle, buffalo, sheep, and goat; domestic animals with wing as chicken, turkey, goose duck and meats appropriate for human nutrition from rabbit and pig" (Anonymous, 2010).

Meat, with a history as long as human history, has become the most important food for human in time (Aritasi, 2009). Meat, which has an important place in animal based nutrient, is a protein with high biological values. Meat consume is higher in high income groups.

Nowadays, meat consuming level is an indicator of development of countries. The reason for this is the importance of animal proteins such as meat, milk and egg in human nutrition. Parallel to developing countries' social and economic advancements, meat consuming structure changes and consuming level rises (Kan and Direk, 2004).

In less developed countries, carbohydrate based nutrition is higher and protein based nutrition is very low. Main problem with food of less developed countries is high food expenses and insufficient nutrition. In a study carried out by World Bank, it is found that minimum calorie need for survival is $2.400 \mathrm{k} / \mathrm{cal}$ daily and people who cannot afford this is said to be "definite poor" (Anonymous, 2001; Yuce and Ozbek, 2006).

According to 2012 statistics, average meat consume on earth is $38.7 \mathrm{~kg}$ but this number in Turkey is $12 \mathrm{~kg}$ per person. These numbers are in USA $37.2 \mathrm{~kg}$ and $16.9 \mathrm{~kg}$ in EU (FAO, 2013). If 90 gr of meat consuming is sufficient for enough animal protein, it is found that the number should be $33 \mathrm{~kg}$ yearly per person (FAO, 2009). On earth, average cattle meat consumption is $9 \mathrm{~kg}$, this number is $41 \mathrm{~kg}$ in USA and $19 \mathrm{~kg}$ in EU. Despite this, the number is very low in Turkey as $4 \mathrm{~kg}$. (FAO, 2009). According to studies, in Turkey animal protein consumption is 19 gr/Daily average per person (Alpan, 1993; Odabasioglu et al, 1995; Arpacik, 1999). This value suggests that there is a protein shortage in Turkey.

Consumer's purchase, usage, activity and process of products is called purchase behavior (Albayrak, 2000). As conscious consumers increasing in society, the concept of consumer behavior became important. Consumer behavior shows why, how and when consumer corresponds to personal needs with products and services.
Determination of exact consumer behavior helps show the direction of consumer's needs and demands (Demirel and Yoldas, 2005).

Usually there is a determination about animal protein demand, but it is possible that this demand structure changes and people orientate for competing brands in time. This situation is about consumer's culture level, income, social level and development process. As culture, civilization level and income level raises, carbohydrate based nutrition decays and protein based nutrition raises.

In this study, red meat and meat products consuming and purchasing behaviors of people living in Ankara's urban areas is investigated.

\section{Materials and methods}

Main material of this study firstly consists of a survey completed in urban areas near Ankara. Also related scientific studies and data sets from a variety of foundations are used.

Sample volume of the research is calculated 338 using, "Main Mass Ratio Based Simple Occurrence Probability Sampling" method. This sampling method is used mostly on customer related family researches (Newbold, 1995).

n: Sample Size,

$$
\mathrm{n}=\frac{\mathrm{z}^{2} *(\mathrm{p} * \mathrm{q})}{\mathrm{d}^{2}}
$$

z: 1,96 (standard z-value for \%95 reliability level),

$\mathrm{p}$ : Main mass ratio which have prior knowledge about the subject or specific characteristics based on prediction. In this study, there is no prior knowledge about individuals which shape their consume behavior on food reliability. In such cases, to make sample size as big as possible it is suggested to take $\mathrm{p}$ value $\% 50$ in order to make $\mathrm{p}(\mathrm{p}-1)$ product as big as possible

$\mathrm{q}$ : $(1-\mathrm{p})$ main mass ratio which does not have related characteristic.

$\mathrm{d}$ : Taken error tolerance level. In this study it is taken $\pm \% 5$.

Income level and income distribution of consumers may cause big differences on purchase power (Mucuk, 2001). For this cause, completed surveys were separated into 3 groups; high, middle, low (Table 1).

Percent Proportion Method is used to analyze the data. Also Likert Scale is used for some questions and average of the given points for each question is taken for evaluation.

Table 1 Interviews families with different income levels

\begin{tabular}{l|lcc}
\hline Income & \multicolumn{4}{|c}{$\begin{array}{c}\text { Number of } \\
\text { Groups }\end{array}$} & Income Level (Monthly) & $\begin{array}{c}\text { Houses } \\
\text { Low }\end{array}$ & $\begin{array}{l}\text { Houses with less than } \\
500 \text { \$ Income }\end{array}$ & 14 & 4 \\
Middle & $\begin{array}{l}\text { Houses with between } \\
500 \text { \$ } 1500 \text { \$ Income }\end{array}$ & 138 & 41 \\
High & $\begin{array}{l}\text { Houses with more than 1 } \\
500 \text { \$ Income }\end{array}$ & 186 & 55 \\
\hline Total & & 338 & 100 \\
\hline
\end{tabular}




\section{Results}

Red meat sector in Turkey

Turkey, with is geographical aspects, has appropriate features and potential for any animal product production. Turkey used its potential to raise its animal assets not efficiently but in number until 1980. But after 1980, problems with taming of races, enough amounts of cheap and quality feeds caused animal assets to decay. Especially in 2000s this became widespread. Supply became insufficient in domestic market and prices raised. Meat import was made in order to lower the prices.

There has been an increase in Turkey's animal assets lately. 2012 statistics indicate that total cattle number is 13.9 Million, total sheep number is 27.4 million, and total goat number is 8,4 million (TSI, 2013). In this period 2.8 million bovine and 5.5 million ovine has been cut for meat production. $\% 87.5$ of obtained meat is cattle meat, $\% 10.6$ sheep meat and \%1.9 is goat meat (TSI, 2013).

Despite the fact that the number of animals has increased lately, it did not reach the desired level. Red meat import has risen from little if any to a serious level in Turkey during last 3 years. Especially, red meat import in 2011 reached a record level of 826 thousand tons. Nevertheless, red meat export has been 663 thousand tons in the same period (TSI, 2013).

Animal husbandry sector in Turkey has not reached the desired level due to management structure, in-efficient feed and breeding policy, health, producer and marketing organization problems and the lack of sustainable animal husbandry policy (TKB, 2006).

\section{Properties of interviewed families}

In research area, average residence is 26.9 years, and average population for each house is 3.4. Average women age is 43.8 and average men age is 47.4 . Education level with higher than college in women is $\% 14.3$, and $\% 39.8$ in men. Average monthly income, average monthly expense, and average monthly expense for food in Ankara urban area is given on Table 2. Expense for food in total income is around \%34. This ratio for families with low income is $\% 53$, for families with middle income is $\% 35$ and for families with high income is \%33. It shows that as income level increases, expense ratio for food decreases.

Table 2 Economic condition of families for different income levels (\$/month)

\begin{tabular}{l|ccc}
\hline Income & & Total & Food \\
Groups & Total Income & Expense & $\begin{array}{c}\text { Expense } \\
\text { Low }\end{array}$ \\
Middle & 1119 & 501 & 260 \\
High & 2531 & 1003 & 395 \\
\hline Average & 1552 & 1985 & 835 \\
\hline
\end{tabular}

Purchase behavior of consumers

$\% 40$ of total meat production and \% 55 of red meat production in World is pork (FAO, 2013). In Turkey there is no such behavior for pork meat consumption as well as production. Red meat consumption in families included in research consists of cattle and sheep meat (Table 3).

As families with low income prefer butcher's shop for purchase, families with middle and high income prefer butcher sections in supermarkets (Table 4 ).

There are a lot of factors effecting the consumer's purchase decision. Especially price and health related factors affect the decision of the consume (Table 5).

There has been a decrease in red meat consumption in Turkey lately. Health risks of Meat quality and personal health problems affect this decrease. Apart from these, high fat ratio in animals and increase in meat prices also is effective (Figure 1).

Table 3 Red meat consumption per individual $(\mathrm{kg})$

\begin{tabular}{l|rrrrrrr}
\hline Income & & & & & & & \\
Groups & $\mathrm{Ct}$ & $\mathrm{Sh}$ & $\mathrm{Sa}$ & $\mathrm{Wi}$ & $\mathrm{Sa}$ & $\mathrm{Br}$ & $\mathrm{Gi}$ \\
\hline Low & 0.88 & 0.50 & 0.35 & 0.25 & 0.25 & 0.20 & 0.10 \\
Middle & 1.68 & 0.47 & 0.58 & 0.26 & 0.36 & 0.10 & 0.15 \\
High & 2.38 & 1.06 & 0.87 & 0.38 & 0.38 & 0.45 & 0.26 \\
\hline Average & 1.84 & 0.67 & 0.66 & 0.30 & 0.36 & 0.21 & 0.19 \\
\hline Ct=Cattle, & Sh=Sheep, & Sa=Sausage, & Wi=Wiener, & Sa=Salami, \\
Br=Bresaola, Gi=Giblets & \multicolumn{7}{l}{ Sa }
\end{tabular}

Perception level of the customers in research area on meat and meat related products are investigated (Figure 2 ). It is understood that an important amount of customers are in doubt about food reliability.

The information about meat and meat related products given by companies is important for protection of costumers, decision process of customers and competition between different companies. Labels, which is the most important and common way to pass information, help consumers pick healthy and conscious product by including ingredients, price, expiration date, use age, origin and especially breeding values lately (Ozgul and Aksulu, 2006). \%61.54 of the customers included in research read the label of the products before purchasing (Figure 3 ). It is a concern that almost $1 / 3$ of customers do not read the labels. This could be explained by distrust about the information written on labels. As a matter of fact, only $\% 30.47$ of customers believes that the information on the labels is telling the truth (Figure 4).

It is noted that the customers mostly pay attention about price, grammage and storage conditions on labels. Customers usually take no account of vitamin or mineral values, calories, and its benefits on health.

As customers evaluate a product's quality, they take inner and outer clues in account. In situations where the customer can not differ products from its physical appearances (inner properties like size, color, smell, taste) or when they have no personal experience, they take outer properties such as brand image, price, packaging, seller image, advertisement and the origin of the product in consideration. Outer quality measures such as brand name is also included in research. Brand name is usually a kind of insurance for the customer (Yukselen, 2001). In research it is noted that $\% 54$ of customers prefer wellknown brands. Out of these customers almost $2 / 3$ of them change the brand from time to time. But $\% 32.25$ of them prefers the same brand all the time (Figure 5).

The factor affecting the customers purchasing red meat products who prefer branded products are; less health risks, quality controls and the control of feeding conditions of animals. The most important reason is found to be food reliability concerns.

The reasons for customers which do not prefer wellknown brands are the thought that the branded and nonbranded products having the same quality, the higher prices of branded products and the lack of routine about using branded products. 
Table 4 Places of red meat purchase of consumers $(\%)$

\begin{tabular}{l|l|ccccccc}
\hline \multirow{3}{*}{ Products } & & & & \multicolumn{2}{c}{ Supermarket } & \multicolumn{2}{c}{ Hypermarket } \\
& Income & & & $\begin{array}{c}\text { Butcher } \\
\text { Section }\end{array}$ & $\begin{array}{c}\text { Delicatessen } \\
\text { (Rack) }\end{array}$ & $\begin{array}{c}\text { Butcher } \\
\text { Section }\end{array}$ & $\begin{array}{c}\text { Delicatessen } \\
\text { (Rack) }\end{array}$ \\
& Groups & Butcher's Shop & Market & Total \\
\hline \multirow{5}{*}{ Cattle Meat } & Low & 34.15 & 22.20 & 24.14 & 4.32 & 13.04 & 2.15 & 100.00 \\
& Middle & 26.17 & 13.52 & 35.18 & 4.96 & 15.85 & 4.32 & 100.00 \\
& High & 23.96 & 16.67 & 35.42 & 2.08 & 17.71 & 4.16 & 100.00 \\
& Average & 28.28 & 17.17 & 32.32 & 4.55 & 13.64 & 4.04 & 100.00 \\
\cline { 2 - 9 } Sheep Meat & Low & 34.00 & 24.00 & 24.52 & 5.31 & 7.55 & 4.62 & 100.00 \\
& Middle & 29.63 & 17.28 & 30.86 & 7.00 & 11.93 & 3.30 & 100.00 \\
& High & 23.00 & 22.00 & 33.00 & 5.00 & 15.00 & 2.00 & 100.00 \\
& Average & 30.01 & 18.12 & 31.15 & 7.00 & 10.52 & 3.20 & 100.00 \\
\hline
\end{tabular}

Table 5 Factors effecting the purchase decision of consumers

\begin{tabular}{l|cccc}
\hline \multirow{2}{*}{ Criteria's } & \multicolumn{3}{c}{ Income Groups } \\
\cline { 2 - 5 } Price & Low & Middle & High & Average \\
Origin (Which area animal was breeded) & 3.43 & 3.95 & 3.50 & 3.63 \\
Feeding type (rangeland or nourishing) & 2.46 & 3.10 & 3.20 & 2.92 \\
Race & 3.08 & 3.09 & 2.96 & 3.04 \\
Age of the animal & 2.85 & 2.93 & 2.56 & 2.78 \\
Meat fat & 3.08 & 3.18 & 3.24 & 3.16 \\
Color & 4.07 & 3.71 & 3.99 & 3.92 \\
Package & 3.07 & 3.20 & 3.03 & 3.10 \\
Place where it is purchased & 3.71 & 3.76 & 3.95 & 3.81 \\
Labeling & 4.14 & 3.80 & 3.84 & 3.93 \\
Freshness & 3.93 & 3.98 & 3.92 & 3.94 \\
Brand & 3.71 & 4.44 & 4.35 & 4.17 \\
Guarantee of meat's health & 3.33 & 3.35 & 3.56 & 3.41 \\
Ecologic / Organic & 4.29 & 4.24 & 4.27 & 4.26 \\
Advertisement / Promotion & 4.23 & 3.75 & 3.94 & 3.97 \\
Meat protein & 3.00 & 2.66 & 2.59 & 2.75 \\
Suggested by experts & 3.17 & 3.58 & 3.46 & 3.40 \\
Health benefits & 3.64 & 3.73 & 3.63 & 3.67 \\
\hline
\end{tabular}

NOTE: 1: Not important, 5: Very important

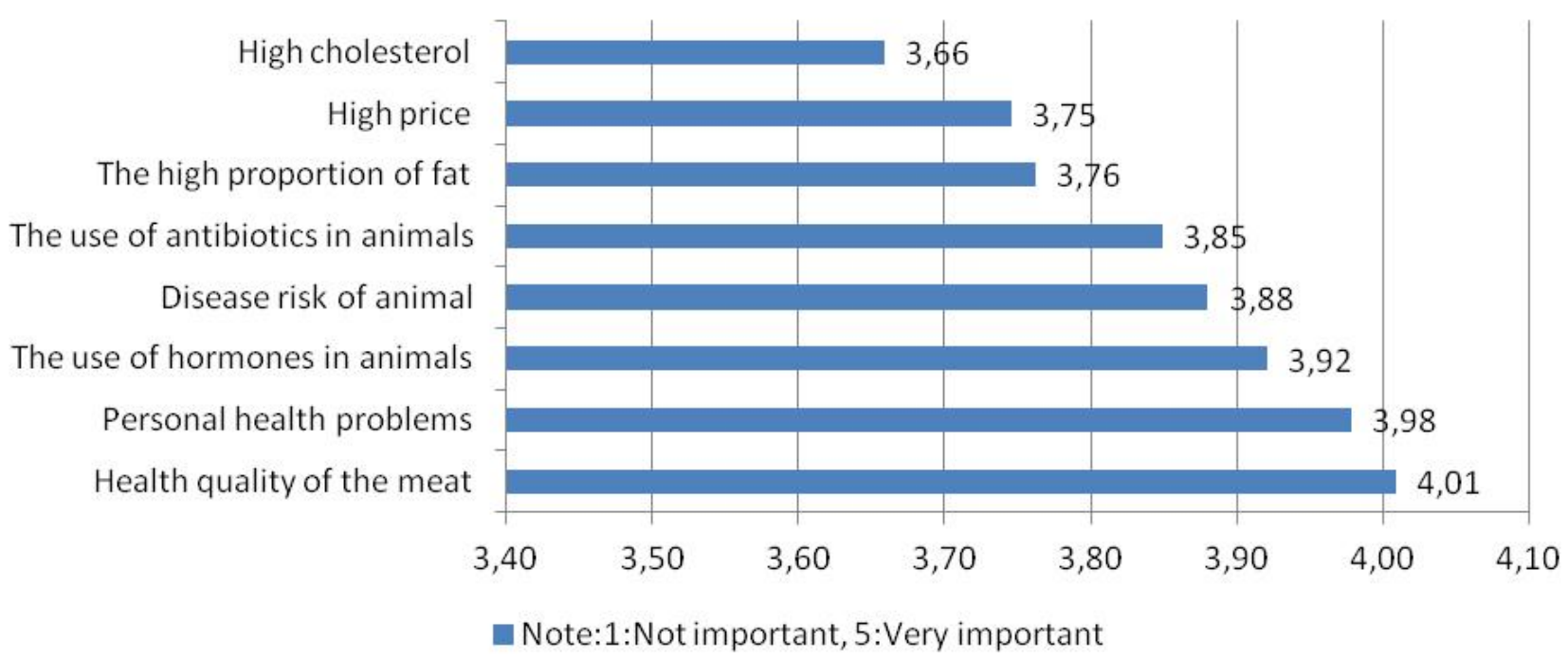

Figure 1 Factors affecting red meat consumption change of consumers 


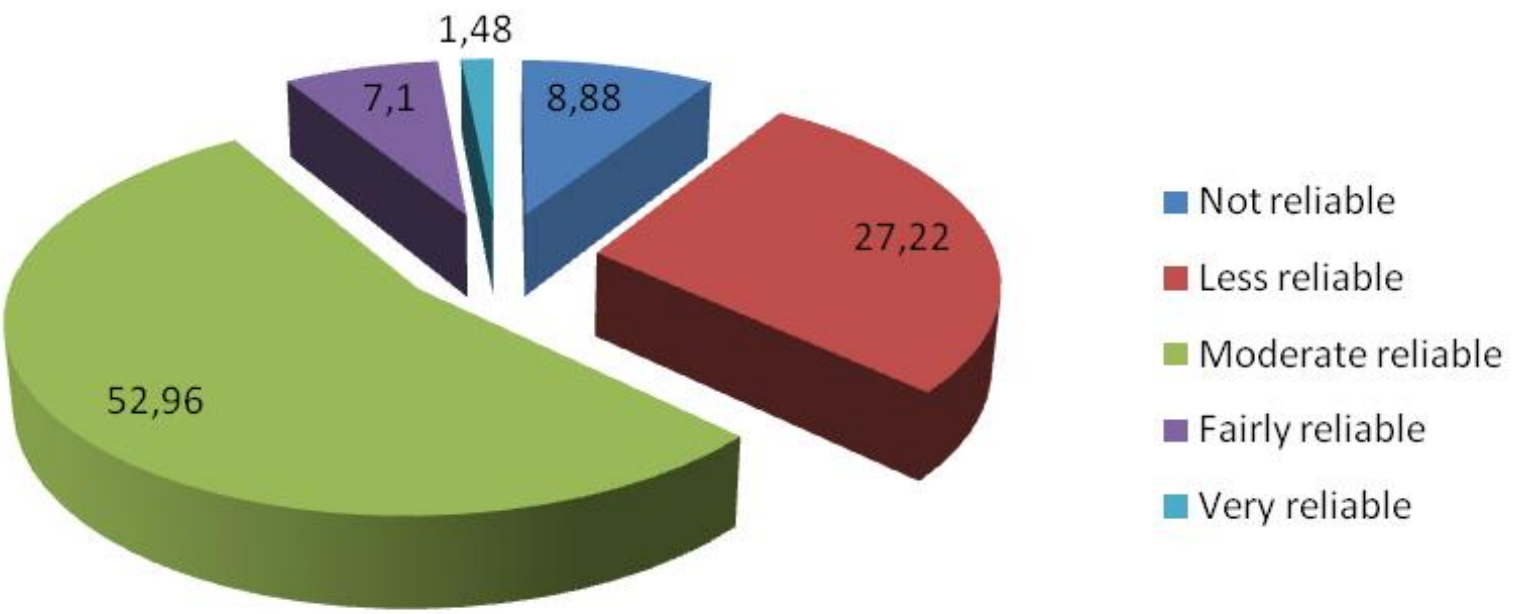

Figure 2 Perception level of customers about food reliability of meat and meat related products

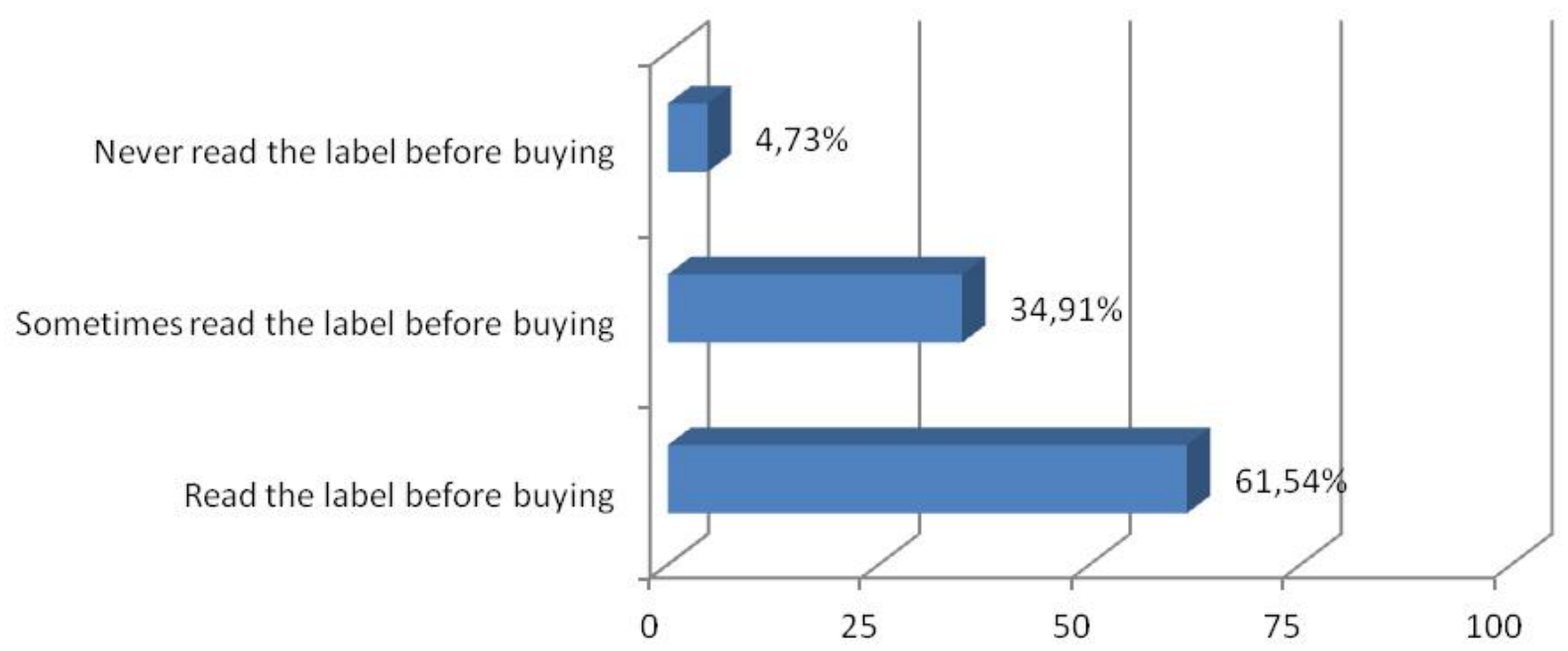

Figure 3 Consumers' behavior of reading labels

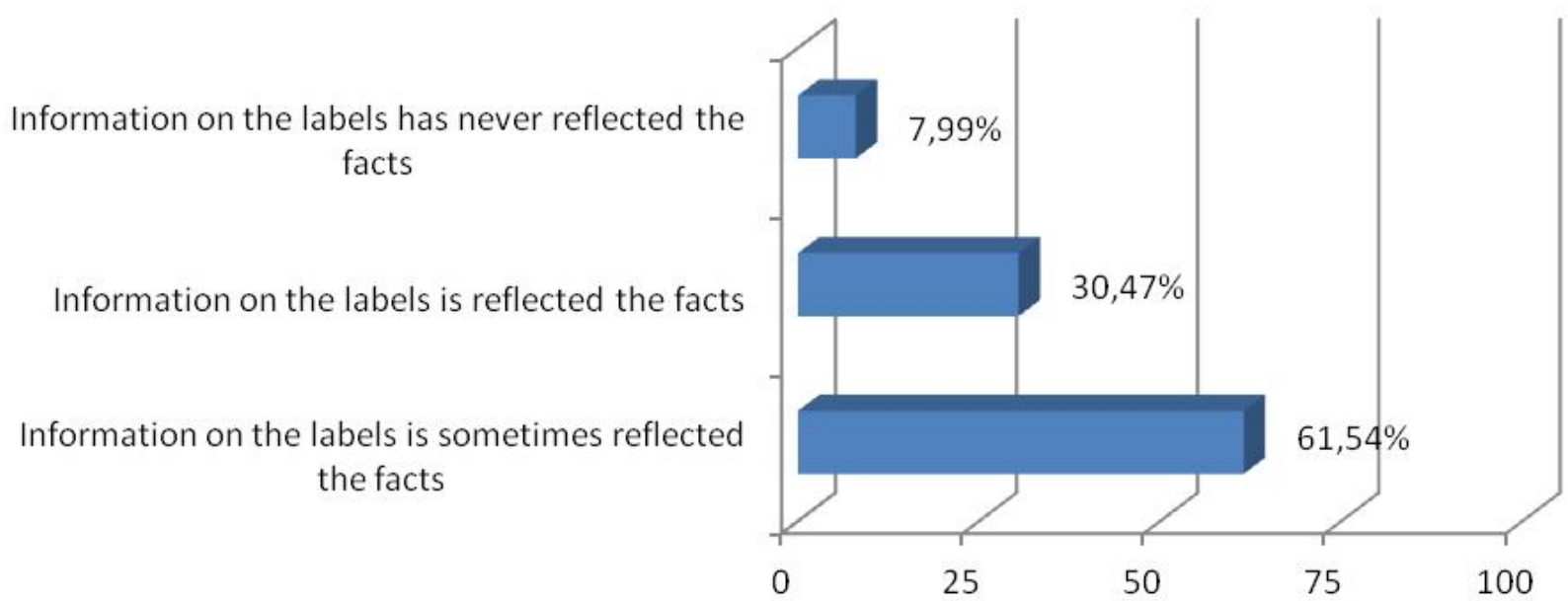

Figure 4 Consumer perception of trust on the information included in labels 


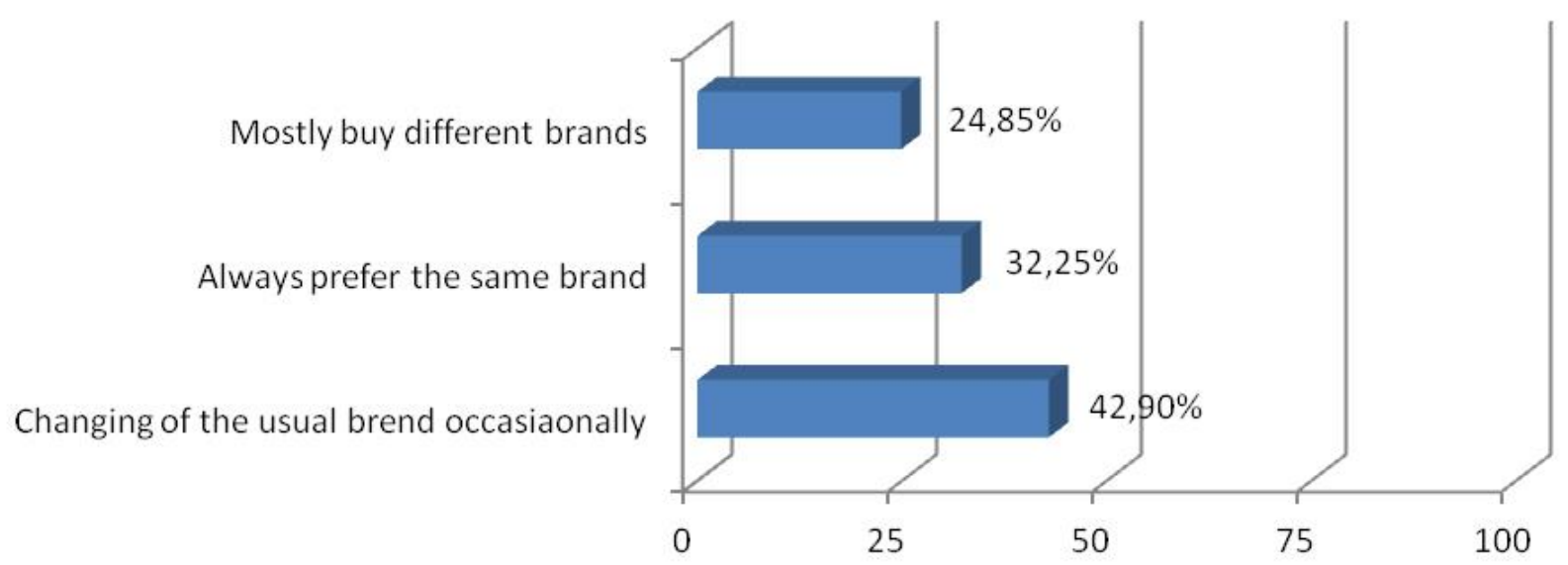

Figure 5 Alteration frequency of customers purchasing red meat products

Usage of branded product is more popular
Usage of branded product is symbol of prestige

Contain less oil

The origin of the meat is known as geography

It does not contain any hormone

More tastefull

Animal feeding is under control

Less risks for human health

The best meat is quality controlled

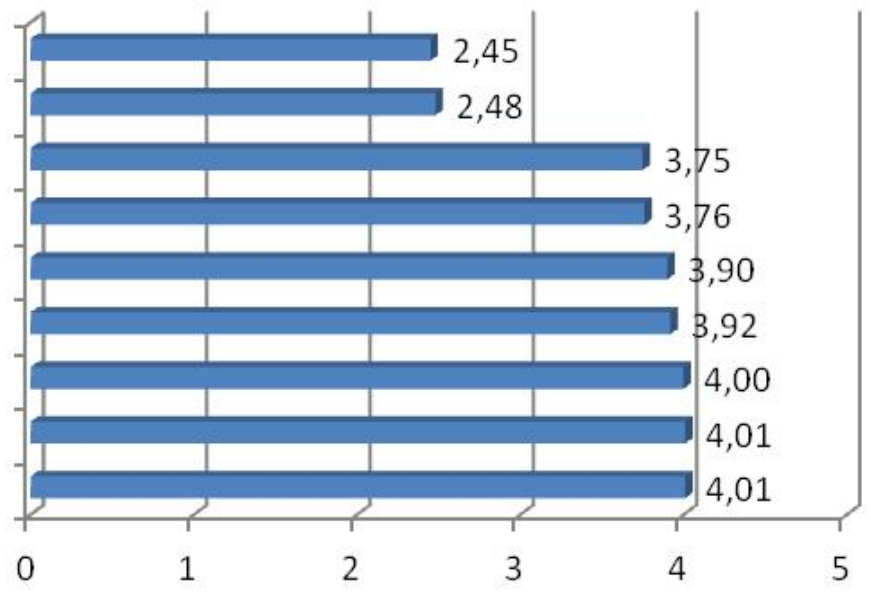

Note: 1:Not important, 5:Very important

Figure 6 Factors affecting the customers purchasing red meat products who prefer branded products
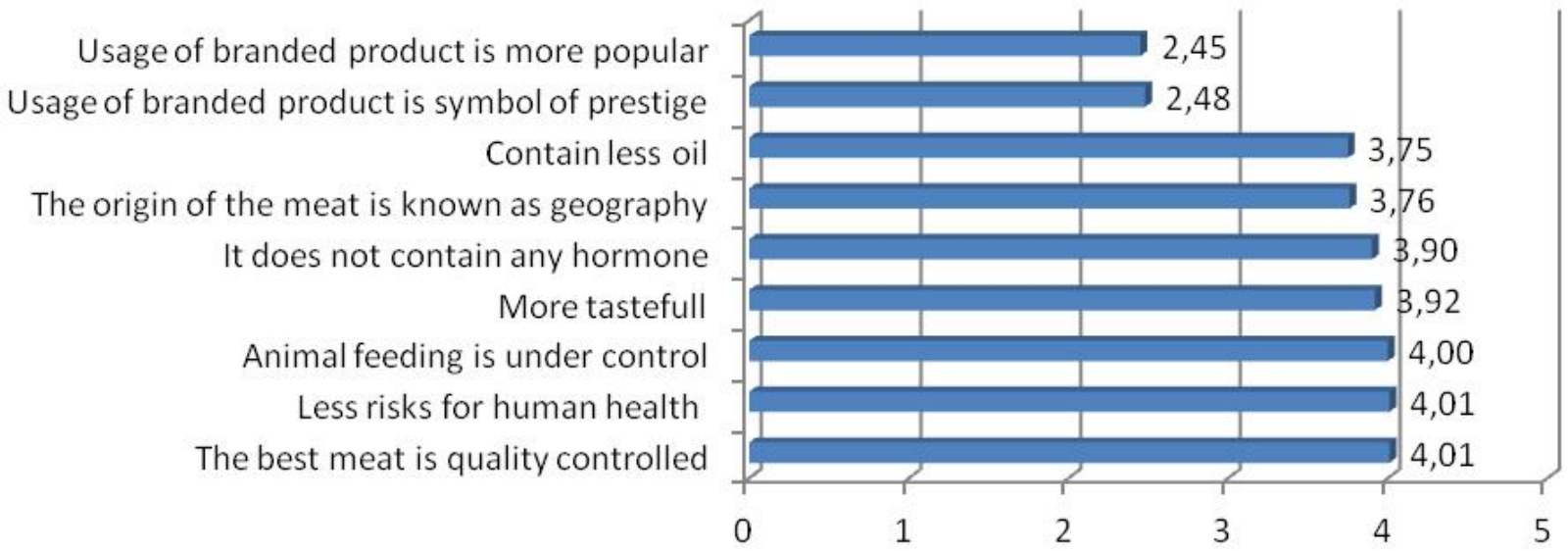

- Note: 1:Not important, 5:Very important

Figure 7 Factors affecting the customers which do not prefer well-known brands 


\section{Discussion}

Health of individuals forming society depends on sufficient and well-balanced nutrition. Animal protein in sufficient and well-balanced nutrition is very important. Meat, located in animal proteins, is an important protein source for nourishment. People in Turkey do not get enough animal protein. Increase of meat and meat related product prices due to recent decrease of animal assets in Turkey is effective on this. It is indicated that as the level of income increases, food expenses increase as well.

Mostly consumed red meat in research area is cattle meat, as it is in Turkey. A relation between purchase behaviors of consumers with level of income is detected. It is determined that consumers with high income level prefer supermarkets instead of butcher's shops.

Research result Show that many factors affect the purchase behavior of consumers. It is found that the most important factor for consumers is food reliability. In the meantime, consumers suggest that the most important factor affecting this decrease in red meat and red meat related product consumption is possible health risks of meat.

Most consumers feel insecure about the information on labels. The most important reason for consumers choosing well-known brands for red meat and red meat related products is the concern about food reliability.

Food reliability is one of the primary subjects which governments of all countries work particularly about and make legal adjustments. There has been many legal adjustments on this field in Turkey. Municipalities, Ministry of Food Agriculture and Animal, and Ministry of Health worked on food quality inspection until today. This created conflict between establishments about authorization and service. With new food law, all authorization gathered at Ministry of Food, Agriculture and Animal. But studies show doubts of consumers about food reliability. It is understood that legal adjustments are not applied enough. Especially tight food inspections would be positive on consumer behavior.

\section{References}

Albayrak M. 2000. Ankara Ilinde Gida Maddeleri Paketleme ve Etiketleme Bilgileri Hakkında Tuketicilerin Bilinc Duzeyinin Olculmesi, Gida Maddeleri Alim Yerleri ve Ambalaj Tercihleri Uzerine Bir Arastirma. Turkiye Ziraat Odalari Birligi Yayinlari, Ankara.

Alpan O. 1993. Sigir Yetistiriciligi ve Besiciligi. Ankara Universitesi Veteriner Fakultesi, (3.bask1). 117s. Ankara.

Anonymous. 2001. Republic of Turkey Ministry of Development. Sekizinci Bes Yillik Kalkinma Plani, Gelir Dagiliminin Iyilestirilmesi ve Yoksullukla Mucadele Ozel Ihtisas Komisyon Raporu, Ankara. http://www.kalkinma.gov.tr/Kalkinma.portal Accessed: 07.05.2013.
Anonymous. 2010. Ankara Health Directorate. http://www.asm.gov.tr/ Accessed: 09/05/2013.

Aritasi C. 2009. Et ve Balik Isleme Teknolojisi Ders Notlari. Namik Kemal Universitesi, Tekirdag.

Arpacık R. 1999. Entansif Sigir Besiciligi. Sahin Matbaasi (3. baski), Ankara.

Demirel Y, Yoldas MA. 2005. Yeni Ekonomide Tuketici Satin Alma Davranıslarini Etkileyen Faktorler. Pazarlama Dunyasi Dergisi. 3: 60-64.

FAO. 2009. Food and Agriculture Organization of the United Nation. Statistical Database. http://www.fao.org/statistics/en/ Accessed: 07.06.2013.

FAO. 2013. Food and Agriculture Organization of the United Nation. Statistical Database. http://www.fao.org/statistics/en/ Accessed: 07.06.2013.

Ilgu E, Gunes H. 2002. Siyah-alaca Irkindan Erkek Sigirlarin Ozel Isletme Kosullarindaki Besi Performansları Uzerinde Arastirmalar. Istanbul Universitesi Veterinerlik Fakultesi Dergisi 28: 313-335.

Kan A, Direk M. 2004. Course of Red Meat Prices in the Konya Province. Selcuk Universitesi Ziraat Fakultesi Dergisi 18: 35-40.

Karabacak A, Direk M. 2007. Tarimda Kuresellesme ve Turkiye. Journal of Azerbaijani Studies: 486-499. Sosyal Bilimler Enstitusu Dergisi. 14: 529-551.

Mucuk K. 2001. Pazarlama Ilkeleri. Turkmen Kitabevi, Yayin No:83, İstanbul.

Newbold P. 1995. Statistics for Business and Economics. Prentice-Hall International, New Jersey, 867 p.

Odabasioglu F, Kayardi S, Yilmaz O. 1995. Melez Sigir Karkaslarindan Elde Edilen Etlerin Kaliteye Gore Siniflandirilmasi ile $\mathrm{Bu}$ Etlerin Fiziksel ve Kimyasal Analizi. Hayvancilik Arastirma Dergisi 5: 35-38.

Ozgul E, Aksulu I. 2006. Ambalajli Gida Urunlerinde Tuketicilerin Etiket Duyarliligindaki Degisimler. Ekonomi, Isletme, Uluslararasi Iliskiler ve Siyaset Bilimleri Dergisi, Cilt 6, Sayı 1, Ocak, 2006.

TKB. 2006. Republic of Turkey Ministry of Food, Agriculture and Livestock. http://www.tarim.gov.tr/Sayfalar/Eng1033/Anasayfa.aspx Accessed: 07/06/2013.

TSI. 2013. Turkish Statistical Institute. http://tuik.gov.tr/UstMenu.do?metod=temelist Accessed: 09.08.2013.

Unver Y, Unusan N. 2005. Okul Oncesinde Beslenme Egitimi Uzerine Bir Arastirma. Selcuk Universitesi Sosyal Bilimler Enstitusu Dergisi. 14: 529-551.

Yagmur C, Gunes E. 2010. Dengeli Beslenme Acisindan Turkiye'de Gida Uretimi ve Tuketiminin Irdelenmesi, VII. Ziraat Muhendisligi Teknik Kongresi, Ankara.

Yuce M, Ozbek MF. 2006. Orta Asya Cumhuriyetlerinde SosyoEkonomik Boyutlariyla Yoksulluk Olgusu Uzerine Bir Degerlendirme. Akademik Bakis. 10: 1-23.

Yükselen C. 2001. Pazarlama Ilkeleri ve Yonetim. 3. Baski, Detay Yayincilik, 388s, Ankara. 